\title{
Erythrocyte Micronucleus Cytome Assay in Passer Domesticus and Environmental Remote Sensing for Inferring the Quality of Wild, Rural and Urban Areas
}

Sofia Elena Mendez ( $\square$ sofiamendez788@gmail.com)

Universidad Juan Agustin Maza https://orcid.org/0000-0002-9191-0098

Arnoldo Ángel Martín Quero

Universidad Juan Agustin Maza

Nora Bibiana María Gorla

CONICET: Consejo Nacional de Investigaciones Cientificas y Tecnicas. Universidad Juan Agustín Maza

\section{Research Article}

Keywords: house sparrow, environmental health, micronucleus, geogragphic information system

Posted Date: October 25th, 2021

DOI: https://doi.org/10.21203/rs.3.rs-786298/v1

License: (c) (i) This work is licensed under a Creative Commons Attribution 4.0 International License.

Read Full License 


\title{
Erythrocyte micronucleus cytome assay in Passer domesticus and environmental remote sensing for inferring the quality of wild, rural and urban areas
}

\author{
Sofía E. Mendez ${ }^{\mathrm{b}}$, Arnoldo A. M. Quero ${ }^{\mathrm{b}}$, Nora B.M.Gorla ${ }^{\mathrm{a}, \mathrm{b}}$ \\ ${ }^{a}$ Consejo Nacional de Investigaciones Científicas y Técnicas, CONICET, Argentina. \\ ${ }^{b}$ Laboratorio de Genética, Ambiente y Reproducción (GenAR). Universidad Juan Agustín Maza, Mendoza, Argentina.
}

Contactauthors: Arnoldo A. M. Quero aamartinquero@gmail.com, Nora B. M. Gorla noragorla@gmail.com

Key words: house sparrow, environmental health, micronucleus, geogragphic information system

\begin{abstract}
The study of biomarkers in free-living birds can help indicate the degree of contamination in distinct environments. In addition, these environments can be characterized through the information provided by satellite images. The objectives of the present study were to analyze the types and quantity of cytogenetic biomarkers in Passer domesticus (sparrow) from three different environments; wild, rural and urban; and to analyze them in the context of land use and anthropogenic actions. Five thousand erythrocytes per bird were analyzed for the following nuclear alterations (NA): micronuclei (MN), nuclear buds, notched nuclei, binucleated cells, nucleoplasmic bridges, nuclear tails, peripheral nuclei and enucleated cells. In the study, wild birds exhibited five types of NA, seven types were found in rural birds; and all types were encountered in urban birds. The only NA that exceeded a frequency of 2 NA/ 1000 erythrocytes were peripheral nuclei in birds from the rural and urban sites, the latter environment characterized by $87 \%$ urban soil and air pollution. The highest frequencies of $\mathrm{MN}$, peripheral nuclei and enucleated erythrocytes were recorded in sparrows from the rural site ( $\mathrm{p} \leq 0.05)$. This area had been sprayed with chlorpyrifos $48 \%$, the most widely used organophosphate in the region. Sparrows from the wild site, made up of $100 \%$ native forest, had higher frequencies of notched nuclei $(p \leq 0.05)$. A precedent is set for the use of environmental remote sensing in a complementary manner with cytogenetic biomarker studies in birds for a joint analysis in environmental assessment.
\end{abstract}

\section{Introduction}

The characterization of land use and land cover is an essential aspect in the analysis of the quality of environments, as it enables you to assess the state of the land and analyze the subsequent impacts on it (Posada and Salvatierra 2016; Avilés-Ramírez et al. 2017; Sepúlveda-Varas et al. 2019). Remote sensing provides images with information for a large number of applications such as land use mapping, urban planning, environmental monitoring and crop management (Cardozo and Da Silva 2013). Satellite images are digitally generated through an electromagnetic interaction that occurs between the satellite and objects on the Earth's surface (Chuvieco 2015). The Landsat 8 satellite has a sun-synchronous, near-polar orbit system with an altitude of $705 \mathrm{~km}$, which ensures full coverage of the Earth's surface and the same solar illumination conditions for all of the areas observed (USGS 2021). The objects present in a satellite image are characterized through various picto-morphological criteria (Cardozo and Da Silva 2013). Remote sensing and Geographic Information Systems (GIS) are used in environmental studies as a tool for monitoring animals, detecting changes in vegetation cover, and creating land use maps, amongst other such studies. This is a technology that works together with remote sensors to provide detailed information and knowledge of the environmental conditions in 
the areas under study and also allows the analysis of the different factors that influence them, providing a detailed and integrated study of the territory (Perpiña et al. 2013).

The quality of environments can be assessed by using animals that behave as bioindicators. Birds are good candidates because they occupy a wide range in trophic levels, are widely distributed, have a long life span, and are sensitive to atmospheric changes (Tietze 2018). Performing cytological and physiological studies in birds from different environments is useful for identifying comparisons; organisms can be affected by urban pollutants of anthropogenic origin and by active ingredients used in production animals, fruit trees and vegetables, particularly those applied to combat insect pests, fungi and weeds, commonly known as pesticides (Ferré et al. 2018a).

The house sparrow (Passer domesticus) is a cosmopolitan species, belonging to the order Passeriformes, known as the songbirds (BirdLife 2021). House sparrows are adaptable to diverse environmental conditions, with a relatively high abundance in ecosystems (categorization of least concern established by the IUCN), they are easy to handle, possess sexual dimorphism and there is extensive knowledge of their biology, life history and ecology (IUCN 2021). One of the biological characteristics of great interest for the development of this study is that a house sparrow has peridomestic and residential habits (Summers-Smith 2003). It exhibits opportunistic foraging strategies adapting to neophobia, as a consequence it is commonly found in both urban and agricultural areas (Anderson 2006; MacGregor-Fors et al. 2017). The fact that sparrows live in close association with humans means that they share potential environmental risks, as well as living close to other species that are common in habitats altered by anthropogenic actions. Several research studies have attempted to use sparrows as bioindicators of potential hazards posed by environmental contaminants to the health of other wildlife species (Gragnaniello et al. 2001; Pan et al. 2008).

Biomarkers are molecules, cellular structures, and behaviors, which can reflect changes occurring in a biological system. Cytogenetic biomarkers reflect alterations due to spontaneous causes or induced effects resulting from the exposure of an organism, ideally a bioindicator, to a xenobiotic agent (Garte and Bonassi 2005; Quero et al. 2016, 2019). Micronuclei $(\mathrm{MN})$ are well recognized biomarkers of genetic damage that are produced by genotoxic agents acting at the subcellular level. It is postulated that they may be related to the generation of mutagenic and carcinogenic processes in animals and humans (Fenech et al. 2011; Ferré et al. 2018b; Aiassa et al. 2019). The Micronucleus - Cytome (MN - Cyt) assay can potentially be performed in any tissue, with simplicity and rapid results it allows simultaneous detection of multiple events indicating chromosomal instability (Fenech 2020). Using this assay, field biomonitoring can be performed in animal and human populations at risk of genetic damage (Ferré et al. 2018b) and also in experimental groups in a laboratory (Caramello et al. 2019). Nucleated erythrocytes from birds are useful in the MN-Cyt assay to evaluate and monitor ecosystems that have been altered by genotoxic agents (Jones 2015; Quero et al. 2019).

The objectives of the present study were to analyze the type and quantity of cytogenetic biomarkers in house sparrows from three environments; wild, urban and rural, all belonging to the same phytogeographic region and to analyze them in the context of land use, and anthropogenic actions on them, characterized by using visual and digital analysis of satellite images.

\section{Materials and methods}

Characteristics of the sampling sites

The three sites under study belong to the Monte phytogeographic region which is one of the most extensive in Argentina. 
The first is the Wild site (W): Nacuñán Biosphere Reserve (Fig. 1) located in the eastern plain of Mendoza province $\left(34^{\circ}\right.$ $02^{\prime} 00^{\prime \prime} \mathrm{S}, 67^{\circ} 55^{\prime} 00^{\prime \prime} \mathrm{W}$ ), with an average altitude of 583 m.a.s.l. The reserve covers an area of 12,880 ha and is recognized as an Important Bird Area (IBA) by BirdLife (2021), for the identification, documentation, and conservation of critical sites for the world's birds and is also protected by Aves Argentinas (2021).

The second site is the Urban site (U): Headquarters of the Juan Agustín Maza University (Fig. 1) located in the central region of the province of Mendoza (32 53' 57.5" S, 68 48' 3.3" W), 720 m.a.s.l. It belongs to the metropolitan area also known as the Northern oasis, where multiple economic activities are carried out and where air pollutants of anthropogenic origin have been evidenced (Allende et al. 2016).

And finally the third site is the Rural site $(\mathrm{R})$ : fruit production farm in the eastern part of Mendoza province $\left(36^{\circ}\right.$ 37' 13" S, 64 17' 26" W) (Fig. 1), 177 m.a.s.l. At this site, eight days prior to the bird captures, spraying with the insecticide chlorpyrifos $48 \%$ (Lorsban $48^{\circledR}$ ), organophosphate, class II moderately hazardous according to WHO (Caramello et al. 2019), had been carried out.

\section{Characterization of land use at sampling sites}

An imaginary circle with a radius of $2.5 \mathrm{~km}$, corresponding to the flight radius of $P$. domesticus (Summer-Smith 2003), was drawn around the geographic coordinates of each sampling site. The hectares covered by each circle were calculated by spatial analysis (Cisneros et al. 2017) using Google Earth Pro ${ }^{\circledR}$ (2020). The image was saved in KML format to be exported as a vector file to QGIS ${ }^{\circledR}$ Geographic Information Systems (version 3.12.0). A layer overlay was performed in QGIS ${ }^{\circledR}$ to delimit the area to be characterized in infrared color composition. Subsequently, maps were created using Landsat 8 OLI/TIRS satellite images. The final image was exported from QGIS ${ }^{\circledR}$ to Google Earth Pro ${ }^{\circledR}$ to use it as a guide and achieve greater fidelity when calculating the hectares corresponding to each land use and land cover, through visual interpretation on screen with the polygon creation technique (Avilés-Ramírez et al. 2017).

Subsequently, the vegetation covers comprised in each circle were analyzed. Picto-morphological criteria were applied for the visual identification of each land use and land cover. The polygons were recorded and summed in an Excel $^{\circledR}$ spreadsheet. Landsat 8 OLI/TIRS satellite images in L1T format were downloaded from the United States Geological Survey (Cano-Salinas et al. 2017; USGS 2021). All images correspond to the spring-summer season in the southern hemisphere, a time of the phenological cycle in which the vegetation is vigorous (Chuvieco 2015). Images with less than $10 \%$ cloud cover were selected. Subsequently, they were pre- processed through QGIS ${ }^{\circledR}$ and GRASS ${ }^{\circledR}$ (Geographic Resources Analysis Support System) (version 7.8.2) (Rodríguez-Valero and Alonso-Sarria 2019) in the SCP module (Semi - Automatic Classification Pluggin) in which the atmospheric correction DOS 1 (Dark Object Subtraction) of all bands was performed automatically (Picone 2017). A set of bands was created so that they could be used in the desired combinations. The corrected images were loaded again in QGIS ${ }^{\circledR}$ software (version 3.12.0) as raster files and the combination of bands for Landsat 8 OLI/TIRS 5, 4, 3 belonging to the infrared - false color (RGB: NIR - R - G) was performed to highlight vegetation and to be able to characterize land uses and land covers at each site.

\section{Captures of birds and cytogenotoxicity analysis.}

The captures of the sparrows were carried out in the spring. They were carried out by installing ECOTONE ${ }^{\circledR}$ mist nets for 3 days at each site. The nets were opened half an hour before dawn and checked every 20 min. Every caught bird was removed from the nets, prioritizing animal welfare (Ralph et al. 1996). The following sparrows were captured: wild site $n=7$, urban site $n=11$ and rural site $n=15$. A heparinized capillary of blood was extracted from the brachial 
vein and stored at $4^{\circ} \mathrm{C}$ until processing. Finally, absorbent cotton was placed on the vein and only after hemostasis was completed could the bird then be released. One blood smear per bird was taken, fixed in methanol for 1 min, and then stained with Romanowsky type stain. A total of 5,000 mature erythrocytes were analyzed under an optical microscope (1000X) to search for various nuclear alterations (NA). We looked for 8 different types of NA: micronucleus (MN), nuclear buds (Bud), binucleated cells (Bin), notched nuclei (Notch), peripheral nucleus (Periph), enucleated cell (Enuc), bridges (Bridge), and nuclear tails (Tail). For their identification, the criteria adapted and described for birds (Clark and Raidal 2013; Quero et al. 2016) and for reptiles (López-González et al. 2019) were used.

The required authorization was obtained from the Directorate of Renewable Natural Resources (Resolution No. 1170) and the use of protocol No. 119 was evaluated and approved by the Interdisciplinary Commission for the Care and Use of Laboratory, Experimental and Teaching Animals (CICUALE) of UMaza.

\section{Statistical analysis}

The arithmetic mean and the respective standard errors were calculated for each NA in the animals of each study site. The Kolmorogov - Smirnov test was implemented to determine the distribution pattern of the data. For each NA, the Kruskal-Wallis test with pairwise multiple comparison was applied to detect whether the frequencies of the biomarkers analyzed in each group of animals presented any statistical difference between them $(\mathrm{p} \leq 0.05)$. To evaluate whether each population presents a tendency to demonstrate any particular NA according to the site of residence, multivariate principal component analysis was implemented with a total number of 2 components. Statistical analyses were performed in Infostat $^{\circledR}$ (version 2016 software) (Di Rienzo et al. 2016).

\section{Results}

Soil characterization of the wild, rural and urban sampling sites are shown in Figures 2, 3 and 4 respectively. The graphs represent the digital and visual analysis of the areas surrounding these sites. The wild area comprised 1,951.31 ha, of which $100 \%$ was occupied by native forest. The rural area comprised 1,919.62 ha, with a mere $5 \%$ of the area surrounding the sampling point corresponding to agricultural crop covers. The characterized urban area comprised $1,876.02$ ha with the satellite analysis revealing that $87 \%$ of the area was used as urban land.

The study of cytogenotoxicity in the house sparrow sampled in the three sites showed the types and frequencies of NA presented in Table 1. Birds from the urban site presented all the nuclear alterations sought. The NA observed with the highest frequencies were peripheral nuclei in birds from rural and urban sites. In the comparison between sites, the birds that presented three NA with statistical differences with the rest were those from the rural site $(p \leq 0.05)$. The analysis of these results was confirmed by multivariate principal component analysis (Fig. 5).

\section{Discusion}

The selected and digitally transformed satellite images allowed us to characterize the biotic and abiotic components of the sampling sites, and at the same time to contemplate the home range of the house sparrow. With the complementary use of digital and visual analysis, greater accuracy can be generated through the obtained data. Landsat 8 provides images that present improvements compared to predecessor satellites of the same mission (Sánchez-Díaz 2018; Rodríguez-Valero and Alonso-Sarría 2019). It highlights a higher radiometric resolution of 16 bits, which allows greater fidelity in mapping. There are multiple band combinations, of which one of the most outstanding is the infrared colorcomposition, used in the present study, from which it was possible to differentiate the different land uses and land 
covers. GIS are already used to assess avian population dynamics and their relationship with anthropogenic modifications in the environment (Le Louarn et al. 2018; Zhang and Huang 2020). Evidence of increased genotoxicity biomarkers in avian populations near anthropized regions (Queiroz-Baesse et al. 2019; Fonseca-Gonçalves et al. 2020) reinforces the need to combine bioassays with GIS tools to help achieve a more accurate typification of ecosystems.

In the wild site, the natural forest presented a red color with light tones representing photosynthetic vegetation, which can be seen on the right side of the image (Fig. 2), whereas sectors with darker tones indicate areas where the shrub vegetation has a high absorption of sunlight due to the pigments of the leaves, which are visible on the left side of the image. The high percentage of natural bush characterizes the site as an ecosystem that could be considered pristine. In the urban site, the light, white-beige tones indicate urban soil with a high reflectivity due to the sands found in the concrete composition. In this site the vegetation refers to public trees. The high percentage of urban soil of the site represented the component anthropogenic activities and their possible impact on the birds of this site. The increase in population density of the sparrow seems to be equivalent to the increase in the degree of urbanization and it's for this reason that the choice of using this species as a bioindicator of urban pollution is considered appropriate (Anderson 2006; Cid et al. 2018).

In the rural site, the agricultural vegetation presented different colors and tones due to the different types of crops. The fruit trees presented a red color with a light tone and fine texture, the vineyards being predominant in the site, presented a dark red to brown color which represents the shrub vegetation. The forest plantations corresponding to Eucalyptus were red with a light tone, which represents high reflectivity. In the areas where the forest is dense, the tone was darker and in the areas where the forest is sparse, a lighter tone was presented, since it represents a higher reflectivity similar to bare soil (Chuvieco 2015).

With respect to cytogenetic biomarkers, the 3 groups of house sparrow sampled showed all the NA sought in the MN- Cyt assay in mature peripheral blood erythrocytes, with differences according to the sampling site. Birds from the wild site exhibited 5 of the 8 NA searched for, those from the rural site showed 7 of the 8 NA, and those from the urban site exhibited all types of NA.

The statistical evaluation showed significant differences in the sparrows from the rural site, in the frequency of MN, peripheral nucleus and enucleated erythrocytes with increases in comparison to the sparrows from the other 2 sites. $\mathrm{MN}$ are a type of NA that represent damage to genetic material and may be related to the presence of air pollution contaminants generated by anthropization and extreme levels of vehicle circulation (Queiroz-Baesse et al. 2019). Recently, in a study with pigeons with the DBD- FISH technique, the presence of substantial damage in both MNs and buds due to the effect of physical and chemical genotoxic agents has been proven (Cortés-Gutiérrez et al. 2019).

A peripheral nuclei is observed when the nucleus does not occupy a normal central position, but peripheral, also called eccentric nuclei and reported in Caiman latirostris exposed to mixtures of pesticides (López-González et al. 2019). Birds from the rural site presented the highest frequencies of this alteration. In addition, chlorpyrifos had been sprayed in regular agricultural practices during the previous days. We found no data on chlorpyrifosclastogenicity in wildlife birds, although genotoxic effect of chlorpyrifos has been observed in rat liver cells, brain cells and erythrocytes (Mehta et al. 2008; Okonko et al. 2016). This organophosphate is of interest in the study area because it is one of the most widely used insecticides in regional agricultural activity (Ferré et al. 2018a), in addition to its high persistence in the environment and easy dispersion in air, water and soil. The \% of area occupied by crops in the rural site is included within the sparrow's home range, thus representing a probable food supply for the species. It is hypothesized that the sparrows captured and analyzed at this site may have had contact with this pesticide or other substances derived from agricultural activity. 
Erythroplasts are erythrocytes without nucleus and the mechanisms that modulate their formation in birds have not been determined (Clark and Raidal 2013), although several hypotheses have been put forward such as: a controlled enucleation as occurs in mammals; artifacts, which do not seem to be the case in our study given the adequate quality and coloration of the cells, and by the effect of genotoxic agents that result in the ejection of the nucleus. Birds from rural and urban sites presented enucleated erythrocytes. It has been observed that avian populations residing in areas closer to urbanized areas and with lower air quality present an increase in the frequencies of this biomarker compared to those populations that are farther away and with lower levels of air pollution (Fonseca-Gonçalves et al. 2020). Erythrocyte enucleation and apoptotic vesicle formation induced by hydrogen peroxide and high ambient temperatures have also been observed in pigeons (Devyatkin et al. 2006), or by orally administered lead in chickens and pigeons (Hiraga et al. 2008; Cortés-Gutierrez et al. 2019).

In the area characterized as urban, the house sparrows sampled showed nuclear buds with the highest frequencies. According to Fenech et al. (2011) buds represent a process of amplified DNA elimination, complex DNA repair processes, and possibly excess chromosomes from aneuploid cells. A nuclear bud is virtually the same as a micronucleus, except for its connection to the nucleus and buds also contain interstitial or terminal fragments without centromeric or telomeric regions (Dutra et al. 2010). Nuclear buds are associated with MN and other nuclear anomalies such as nucleoplasmic bridges, which are rarely present in our study. In this area, stationary sources constitute $30 \%$ of the air pollution and mobile sources of vehicular origin constitute the remaining $70 \%$. The identification of sulfur compounds, nitrogen oxides, particulate matter, ozone, hydrocarbons, carbon monoxide, polychlorinated biphenyls, polybrominateddiphenyl ethers, dichlorodiphenyltrichloroethane, dioxins and furans has been reported (Allende et al. 2016). Perhaps there may be a relationship between both factors, urban air pollutants and the types and frequencies of NA observed there. This hypothesis promotes studies with a larger number of animals in concomitance with the analytical measurement of the compounds.

The statistical evaluation evidenced significant differences in the sparrows from the wild site in the frequencies of notched nuclei compared to the animals from the other 2 sites. This observation confirms the results we have previously obtained in this same reserve (Quero et al. 2016). The notched nuclei appear as a well-defined cleft of uniform size extending to an appreciable depth in the cell nucleus (Quero et al. 2016). The causes and mechanisms of their formation are not yet known. The presence of lobed, blebbed, notched nuclei and binucleate cells are biomarkers of cytogenotoxicity observed mainly in fish (Anbumani and Mohankumar 2012; Handa and Jindal 2020). Some of these authors hypothesize and discuss its possible origin without reaching a definite conclusion.Nucleated red blood cells of birds, fish and amphibians are proposed as important models to study cellular abnormalities, classifying them into 2 main categories; nuclear abnormalities including binucleates, lobed nuclei, nuclear bud, vacuolated nuclei; and also cytoplasmatic abnormalities, which we are not concerned with in this study (Farag and Alagawany 2018). But we strongly suggest that any increase of knowledge and understanding should be directed to standardize the use of the names given to NA and more importantly, the criteria for analysis and what they mean.

Regarding the selection of the house sparrow as a bioindicator of environments, it can be stated that given their peridomestic habits they represent suitable organisms when it is intended to evaluate the genotoxic effects of atmospheric pollutants affecting human populations (Cortés-Gutiérrez et al. 2019). The bioaccumulation of heavy metals in sparrow tissues suggested considering the house sparrow as an indicator of environmental pollution (Millaku et al. 2015). Other species have been postulated as possible biomonitors due to their close relationship of habits with anthropized 
environments, such as Columba livia, to evaluate genotoxicity of urban air in Italy (Sicolo et al. 2010) and quantification of erythroplastids in Antilophiagaleata in Brazil (Fonseca-Gonçalves et al. 2020).

Finally, the complementary use of the two disciplines used jointly in this study, environmental remote sensing and biomarkers in birds, provided an informative complement to the analysis of the results obtained. This technology has been used to contribute to biodiversity monitoring of plant (Rocchini et al. 2015) and animal species in sites with a high degree of conservation such as Ramsar sites (Palma-Leotta et al. 2019) and in distribution monitoring studies and detection of areas of high bird richness (Su et al. 2018), amongst others uses.

The presence of environmental chemical contaminants with the capacity to damage the structure and/or functioning of genetic material are a threat to animal and human populations, as well as to ecosystem health. House sparrow erythrocytes can be used to evaluate the genotoxicity of xenobiotics and for environmental quality studies. We encourage these types of studies in this cosmopolitan species with life habits in close relationship with humans.

\section{Acknowledgements}

We thank engineers Héctor Cisneros and Cristina Salvatierra for their support and advice on GIS techniques. To Dr. Agustín Zarco for his collaboration in sampling campaigns. To Lic. Yanina Olivi for allowing access and bird sampling activity in her private farm.

\section{Declarations}

Funding The present study was made possible by the financial support of the Juan Agustín Maza University UMAZA (Resolution No. 340/17 Mendoza, Argentina) and from National Council of Scientific and Technical Research (Buenos Aires, Argentina). The samplings were made with prior authorization from the Secretariat of Fauna of the Directorate of Renewable Natural Resources of the Province of Mendoza (Resolution No. 1170).

Conflicts of interest/Competing interests Not applicable

Availability of data and material Data, associated metadata, and calculation tools are available from the corresponding author (https://noragorla@gmail.com and https://aamartinquero@gmail.com).

Code availability Not applicable

Authors' contributions Not applicable

Ethics approval Procedure protocols performed in studies involving animals were approved by the Institutional Commission for the Care and Use of Laboratory Animals (Juan Agustín Maza University UMAZA).

Consent to participate Not applicable

Consent for publication Not applicable

\section{References}

Aiassa D, Mañas F, Gentile N et al. (2019) Evaluation of genetic damage in pesticides applicators from the province of Córdoba, Argentina. Environ Sci Pollut Res 26:20981-20988. https://doi.org/10.1007/s11356-019-05344-2

Allende D, Ruggeri M, Lana B et al. (2016) Inventory of primary emissions of selected persistent organic pollutants to the atmosphere in the area of Great Mendoza. Emerg Contam 2:14-25. http://dx.doi.org/10.1016/j.emcon.2015.12.001

Anbumani S, Mohankumar MN (2012) Gamma radiation induced micronuclei and erythrocyte cellular abnormalities in the fish Catla catla. Aquat Toxicol 122-123:125-132. http://dx.doi.org/10.1016/j.aquatox.2012.06.001

Anderson TR (2006) Biology of the Ubiquitous House Sparrow: From Genes to Populations. New York, United States. 
Aves Argentinas (2021) 100 años junto a vos y la naturaleza. Version 2021. <https://www.avesargentinas.org.ar/>. Accessed 10 July 2021.

Avilés-Ramírez GA, Ruíz-Iriate S, Castellot-Pedraza V et al. (2017) Uso de Google EarthTM para evaluar la pérdida de cubierta vegetal en Chiná, Campeche, México. Agroproductividad 10(5):73-78.

BirdLife (2021) Partnership for nature and people. Version 2021. < https://www.birdlife.org/>. Accessed 10 July 2021.

Cano-Salinas L, Rodríguez-Laguna R, Valdez-Lazalde JR et al. (2017) Detección del crecimiento urbano en el estado de Hidalgo mediante imágenes Landsat. Inst de Geogr 2448-7279. DOI: dx.doi.org/10.14350/rig.52339

Caramello C, Cowper C, Jorge M, Pérez J et al. (2019) Anormalidades morfológicas nucleares en hematíes del pez Prochilodus linneatus expuesto al clorpirifos. Rev Vet 30(2):64-72.

Cardozo O, Da Silva C (2013) Aplicaciones Urbanas de los Sensores Remotos. Rev Geogr Digit. https://hum.unne.edu.ar/revistas/geoweb/Geo20/archivos/cardozo13.pdf. Accessed 15 June 2020.

Chuvieco E (2015) Teledetección ambiental. La observación de la tierra desde el espacio. Barcelona, España.

Cid F, Fernández N, Pérez-Chaca M et al. (2018) House sparrow biomarkers as lead pollution bioindicators. Evaluation of dose and exposition length on hematological and oxidative stress parameters. Ecotoxicol Environ Saf (154):154-61. https://doi.org/10.1016/j.ecoenv.2018.02.040

Cisneros H, Fermani S, Torres J et al. (2017) Configuración espacio - temporal de las variables ambientales en relación a los riesgos naturales en Potrerillos, Mendoza. Bol Estud Geogr (107):51-84.

Clark P, Raidal SR (2013) Evaluation of the erythroplastid component of avian blood. Comp Clin Path 23(4):1117-1123. doi:10.1007/s00580-013-1750-4

Cortés-Gutiérrez EI, García-Salas JA, Dávila-Rodríguez MI et al. (2019) Detection of DNA damage in pigeon erythrocytes using a chromatin dispersion assay. Toxicol Mech Methods 1-8. doi:10.1080/15376516.2019.1701596

Devyatkin AA, Revin VV, Yudanov MA et al. (2006) Effect of hydrogen peroxide on ejection of cell nucleus from pigeon erythrocytes and state of membrane lipids. Bull Exp Biol Med 141(2):261-264. doi:10.1007/s10517-006-0144-x

Di Renzo JA, Casanoves F, Balzarini MG et al. (2016) InfoStat versión 2016. <http://www.infostat.com.ar>. Accessed 10 October 2020.

Dutra A, Pak E, Wincovitch S et al. (2010) Nuclear Bud Formation: A Novel Manifestation of Zidovudine Genotoxicity. Cytogenet Genome Res 128(1-3):105-110. doi:10.1159/000298794

Farag MR, Alagawany M (2018) Erythrocytes as a biological model for screening of xenobiotics toxicity. Chem Biol Interact 279:73-83. doi: 10.1016/j.cbi.2017.11.007

Fenech M, Kirsch Volders M, Natarajan A et al. (2011) Molecular mechanisms of micronucleus, nucleoplasmic bridge and nuclear bud formation in mammalian and human cells. Mutat Res 26(1):125-32. doi:10.1093/mutage/geq052

Fenech, M (2020) Cytokinesis-Block Micronucleus Cytome Assay Evolution into a More Comprehensive Method to Measure Chromosomal Instability. Genes 11(10):1203. doi:10.3390/genes11101203

Ferré D, Quero A, Hernández A et al. (2018a) Potential risks of dietary exposure to chlorpyrifos and cypermethrin from their use in fruit/vegetable crops and beef cattle productions. Environ Monit Assess 190:292. https://doi.org/10.1007/s10661-018-6647-x

Ferré D, Quero A, Hynes V et al. (2018b) Ensayo de micronúcleos de citoma bucal en trabajadores de fincas frutícolas que han aplicado plaguicidas alrededor de quince años. Rev Int Contam Ambient 34(1):23-33. DOI: 10.20937/RICA.2018.34.01.02

Fonseca-Gonçalves V, Alves-Ribeiro PV, Ferreira de Souza-Oliveira C et al. (2020) Effects of urban proximity and the occurrence of erythroplastidsin Antilophia galeata. Environ Sci Pollut Res 27:44650-44655. https://doi.org/10.1007/s11356-020-10057-y 
Garte S, Bonassi S (2005) Linking toxicology to epidemiology: Biomarkers and new technologies-Special issue overview. Mutat Res 592(1-2):3-5. doi:10.1016/j.mrfmmm.2005.05.007

Gragnaniello S, Fulgione D, Milone M et al. (2001) Sparrows as Possible Heavy-Metal Biomonitors of Polluted Environments. Bull Environ Contam Toxicol 66(6):719-26. DOI: 10.1007/s00128-001-0068-0

Handa K, Jindal R (2020) Genotoxicity induced by hexavalent chromium leading to eryptosis in Ctenopharyngodon idellus. Chemosphere 247:125967. https://doi.org/10.1016/j.chemosphere.2020.125967

Hiraga T, Ohyama TK, Hashigaya A et al. (2008) Lead exposure induces pycnosis and enucleation of peripheral erythrocytes in the domestic fowl. Vet J 178:109-114. doi:10.1016/j.tvj1.2007.06.023

IUCN (2021) The IUCN Red List of Threatened Species. Version 2021-1. 〈https://www.iucnredlist.org/ >. Accessed 10 July 2021.

Jones MP (2015) Avian hematology. Clin Lab Med 35:649-659. http://dx.doi.org/10.1016/j.cll.2015.05.013

Le Louarn M, Clergeau P, Strubbe D et al. (2018) Dynamic species distribution models reveal spatiotemporal habitat shifts in native range-expanding versus non-native invasive birds in an urban area. J Avian Biol 49(4), jav-015. doi: 10.1111/jav.01527

López-Gonzalez EC, Siroski PA, Poletta GL (2019) Genotoxicity induced by widely used pesticide binary mixtures on $\begin{array}{llll}\text { Caiman latirostris } & \text { (broad-snouted } & \text { Caiman). } & \text { 232:337-344. }\end{array}$ https://doi.org/10.1016/j.chemosphere.2019.05.218

MacGregor-Fors I, Quesada J, Lee JGH et al. (2017) Space invaders: House Sparrow densities along three urbanagricultural landscapes. Avian Conserv Ecol 12(2):11. https://doi.org/10.5751/ACE-01082-120211

Mehta A, Verma RS, Srivastava N (2008) Chlorpyrifos induced DNA damage in rat liver and brain. Environ Mol Mutagen 49(6):426-433. https://doi.org/10.1002/em.20397

Millaku L, Imeri R, Trebicka A (2015) Bioaccumulation of Heavy Metals in Tissues of House sparrow (Passer domesticus). Res J Environ Toxicol 9(2):107-12. DOI: 10.3923/rjet.2015.107.112

Okonko LE, Ikpeme EV, Udensi OU (2016) Genotoxic effect of chlorpyrifos and cypermethrin in albino rats. Res Journal of Mut 6(1):31-35. https://doi.org/10.3923/rjmutag.2016.31.35

Palma-Leotta M, Torres J, Cisneros H et al. (2019) Aportes de la teledetección para la caracterización de amenazas para la conservación del sitio Ramsar Humedal Llancanelo, Malargüe, Argentina. Bol Estud Geogr 112:83-113.

Pan C, Zheng G, Zhang Y (2008) Concentrations of Metals in Liver, Muscle and Feathers of Tree Sparrow: Age, InterClutch Variability, Gender, and Species Differences. Bull Environ Contam Toxicol 81(6):558-560. DOI 10.1007/s00128007-9168-9

Perpiña C, Martínez-Llario JC, Pérez-Navarro A et al. (2013) Multicriteria assessment in GIS environments for siting biomass plants. Land use poicy 31:326-335. http://dx.doi.org/10.1016/j.landusepol.2012.07.014

Picone N (2017) Comparación de imágenes satelitales Sentinel 2 y Landsat 8 en el estudio de áreas urbanas. Res Gate. https://www.researchgate.net/publication/320705706_COMPARACION_DE_IMAGENES_SATELITALES_SENTINE L_2_Y_LANDSAT 8_EN_EL_ESTUDIO_DE_AREAS URBANAS. Accessed 20 July 2020.

Posada E, Salvatierra H (2016) Análisis comparativo de las metodologías de los sistemas de clasificación de la cobertura de la Tierra LCCS y CORINE, para mapeo de coberturas terrestres. Rev Geogr 157:135-60.

Queiroz-Baesse C, Carneiro de Magalhães-Tolentino V, Morelli S et al. (2019) Effect of urbanization on the micronucleus frequency in birds from forest fragments. Ecotoxicol Environ Saf 171:631-637. https://doi.org/10.1016/j.ecoenv.2019.01.026

Quero A, Zarco A, Landa F et al. (2019) Plasma Cholinesterase Activity in Wild Birds from Undisturbed Woodlands in the Central Monte Desert. Environ Toxicol Chem 00(00):1-9. DOI: 10.1002/etc.4458

Quero AÁM, Ferré DM, Zarco A et al. (2016) Erythrocyte micronucleus cytome assay of 17 wild bird species from the central Monte desert, Argentina. Environ Sci Pollut Res 23(24):25224-31. DOI 10.1007/s11356-016-7638-5 
Ralph C, Geupel G, Pyle P et al. (1996) Manual de métodos de campo para el monitoreo de aves terrestres. https://www.fs.fed.us/psw/publications/documents/psw_gtr159/psw_gtr159.pdf. Accessed 27 September 2020.

Rocchini D, Boyd D, Feret J et al. (2015) Satellite remote sensing to monitor species diversity: potential and pitfalls. Remote Sens Ecol Conserv 2(1):25-36. doi: 10.1002/rse2.9

Rodríguez-Valero MI, Alonso-Sarria F (2019) Clasificación de imágenes Landsat 8 en la Demarcación Hidrográfica del Segura. Rev de Teledetección 53:33-44. https://doi.org/10.4995/raet.2019.11016

Sánchez-Díaz B (2018) La teledetección en investigaciones ecológicas como apoyo a la conservación de la biodiversidad: una revisión. Rev Cient 33(3):243-253. https://doi.org/10.14483/23448350.13370

Sepúlveda-Varas A, Saavedra-Briones P, Esse C (2019) Análisis de cambio de cobertura y uso de suelo en una subcuenca preandina chilena. Herramienta para la sustentabilidad productiva de un territorio. Rev Geogr Norte Gd 72:925 .

Sicolo M, Tringali M, Fumagalli P et al. (2010) Columba livia as a Sentinel Species for the Assessment of Urban Air Genotoxicity. Arch Environ Contam Toxicol 59(3):484-491. doi:10.1007/s00244-010-9488-3

Su J, Piao Y, Luo Z, et al. (2018) Modeling Habitat Suitability of Migratory Birds from Remote Sensing Images Using Convolutional Neural Networks. Animals 8(5):66. doi:10.3390/ani8050066

Summers-Smith J (2003) The decline of the House Sparrow: a review. Br Birds 439-46.

Tietze DT (2018) Introduction: Studying Birds in Time and Space. Bird Species 1-7. doi:10.1007/978-3-319-91689-7_1

USGS (2021) EarthExplorer. Version 2021. < https://earthexplorer.usgs.gov/>. Accessed 10 July 2021.

USGS (2021) Science for a changing world. Version 2021. < https://www.usgs.gov/>. Accessed 10 July 2021.

Zhang Z, Huang G (2020) How Do Urban Parks Provide Bird Habitats and Birdwatching Service? Evidence from Beijing, China. Remote Sens 12(19):3166. doi:10.3390/rs12193166 


\section{Figures}

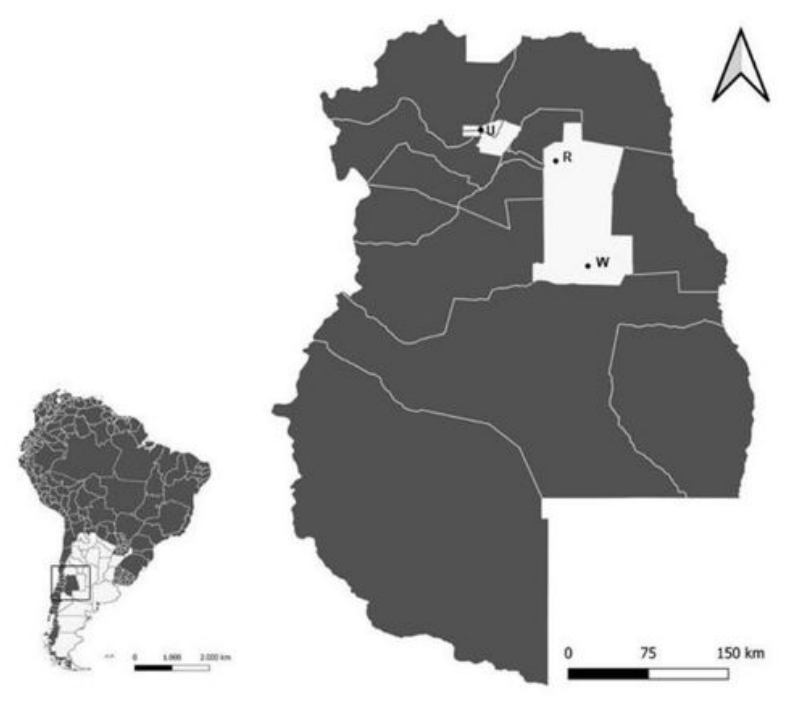

\section{Figure 1}

Geographic map where the three environments under study are indicated (Province of Mendoza, Argentina). W Wild ( $34^{\circ} 02^{\prime} 00^{\prime \prime} \mathrm{S}, 67^{\circ} 55^{\prime} 00^{\prime \prime} \mathrm{W}, 583$ meters above sea level [m.a.s.I]), U Urban ( $32^{\circ} 53^{\prime}$

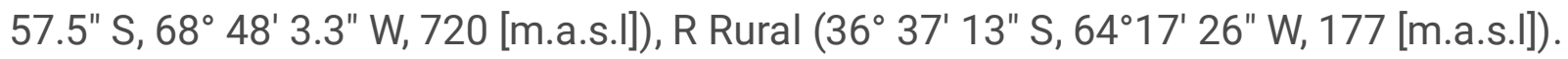
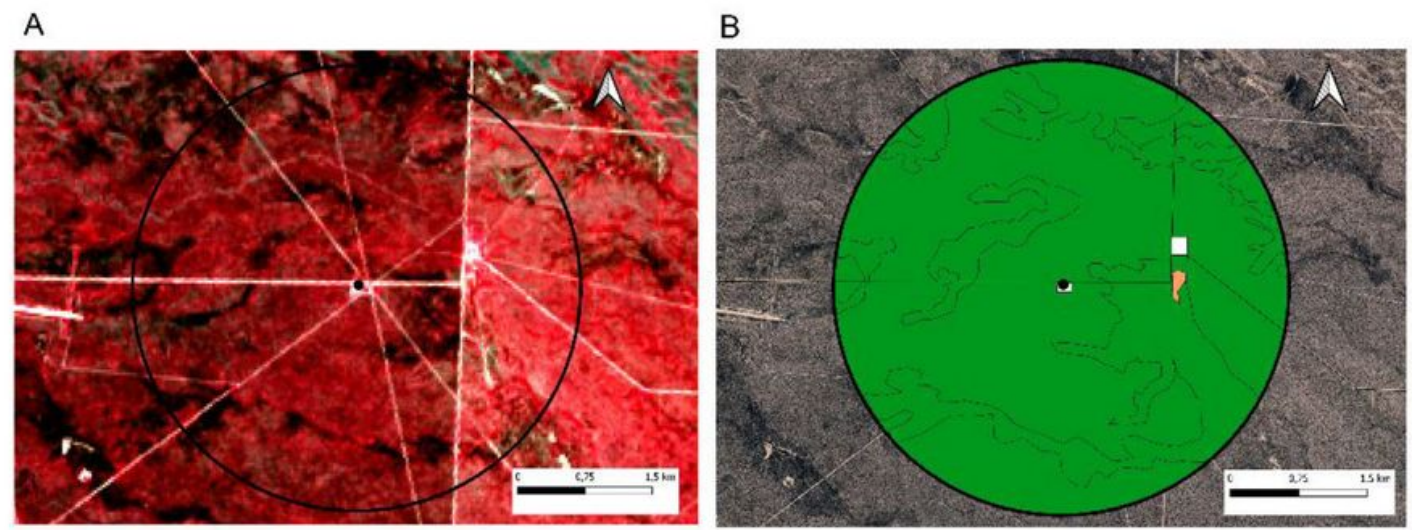

\section{Figure 2}

Wild sampling site ( $34^{\circ} 02^{\prime} 00^{\prime \prime} \mathrm{S}, 67^{\circ} 55^{\prime} 00^{\prime \prime} \mathrm{W}$ ) in Mendoza province and circle that delimits the home range of P. domesticus, (5 km diameter). (A) Landsat 8 satellite image OLI/TIRS, 05/12/17. Combination of bands 5,4,3 (NIR,R,G) Infrared Color-False Color. (B) Polygons of land use and land cover. Satellite image obtained from Google Earth Pro, 05/12/17. Composition 4,3,2 (RGB) belonging to the Natural color. Green: native woodland, beige: bare ground, white: urban ground. 

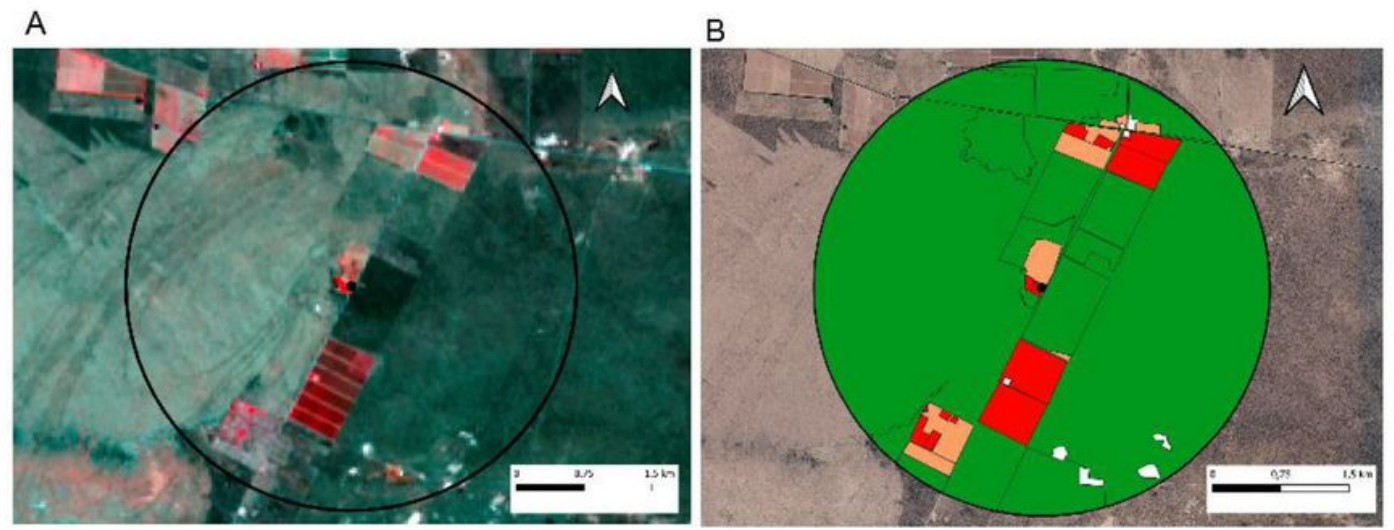

\section{Figure 3}

Rural sampling site $\left(36^{\circ} 37^{\prime} 13^{\prime \prime} \mathrm{S}, 64^{\circ} 17^{\prime} 26^{\prime \prime} \mathrm{W}\right)$ in Mendoza and circle that delimits the home range of P. domesticus ( $5 \mathrm{~km}$ diameter). (A) Landsat 8 satellite image OLI/TIRS, 25/10/17. Combination of bands $5,4,3$ (NIR,R,G) Infrared Color-False Color. (B) Polygons of land use and land cover. Satellite image obtained from Google Earth Pro, 25/10/17. Composition 4,3,2 (RGB) belonging to the Natural color. Green: native woodland, beige: bare ground, grayish white: urban ground, red: agricultural crops.
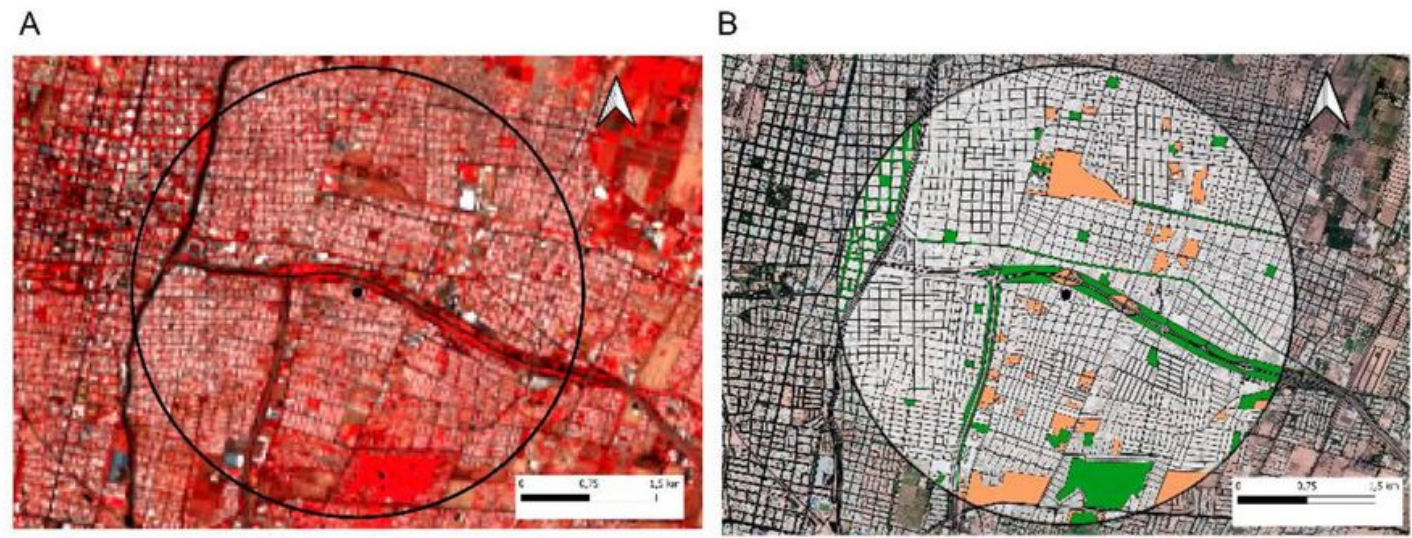

\section{Figure 4}

Urban sampling site ( $32^{\circ} 53^{\prime} 57.5^{\prime \prime} \mathrm{S}, 68^{\circ} 48^{\prime} 3.3^{\prime \prime} \mathrm{W}$ ) in Mendoza and circle that delimits the home range of P. domesticus (5 km diameter). (A) Landsat 8 satellite image OLI/TIRS, 03/10/17. Combination of bands 5,4,3 (NIR,R,G) Infrared Color-False Color. (B) Polygons of land use and land cover. Satellite image obtained from Google Earth Pro, 13/10/17. Composition 4,3,2 (RGB) belonging to the Natural color. Green: native woodland, beige: bare ground, grayish white: urban ground. 


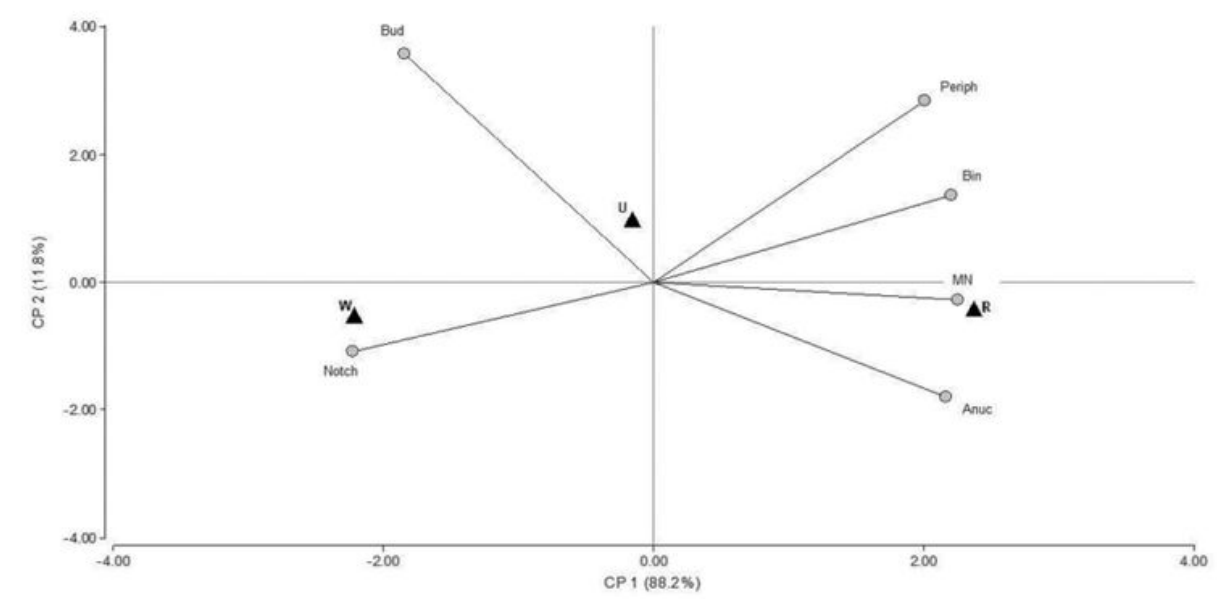

Figure 5

Diagram of the principal component analysis for the variables nuclear alterations in the P. domesticus groups of three environments under study. $W$ wild, $U$ urban, $R$ rural. CP1 principal component 1, CP2 principal component 2, anucleated cells (Anuc), binucleated cells (Bin), notched nuclei (Notch), nuclear buds (Bud), micronuclei (MN), peripheral nucleus (Periph).

\section{Supplementary Files}

This is a list of supplementary files associated with this preprint. Click to download.

- Mendezetal.table1.pdf 